\title{
The hydrodynamics of the Bot River Estuary revisited
}

\author{
L van Niekerk ${ }^{1 \& 2}$, JH van der Merwe ${ }^{1 *}$ and $\mathbf{P}$ Huizinga ${ }^{2}$ \\ ${ }^{1}$ Department of Geography and Environmental Studies, University of Stellenbosch, Private Bag X1, Matieland 7602, South Africa \\ ${ }^{2}$ Environmentek, Estuarine Hydrodynamics, CSIR, Stellenbosch, South Africa
}

\begin{abstract}
For the past 20 years management of the Bot/Kleinmond estuarine system in the south-western Cape has been based on the premise that, barring intervention, the estuary was naturally evolving into a freshwater coastal lake. This paper presents evidence, based on a 20-year series of water-level data, updated runoff estimates from the catchment and dimensional data, that, in the absence of anthropogenic influences, the system is not progressing naturally, but artificially, towards becoming a freshwater system. It is concluded that the increasingly closed state of the Bot Estuary in recent years is most likely due to reduction in runoff from its tributaries and premature artificial breaching of the Kleinmond arm of the system. These findings, coupled with the high conservation importance of the Bot River Estuary, suggest that the current management plan needs urgent revaluation and that the two estuaries cannot be managed separately.
\end{abstract}

Keywords: Bot River Estuary, estuary management, estuary breaching policy, closed estuary, estuarine dimensions, estuarine water levels, estuarine habitat

\section{Introduction}

Estuarine management is a complex task because it deals with the use and care of the interface between land, river and sea where a combination of terrestrial, freshwater and coastal management is essential. For example, estuaries are at the receiving end of a number of bad catchment practices, such as pollution, erosion, excessive water abstraction and impoundment. Because South Africa's rugged coastline has few sheltered embayments, estuaries have become the focus of coastal development (Morant and Quinn, 1999). Poorly regulated activities have destroyed many estuarine habitats by structural development such as mouth stabilisation, low-lying developments, canalisation, land reclamation, pollution and dredging (Boyd et al., 2000; Morant and Quinn, 1999).

Estuaries suffer the unique problem of a boundary location between the jurisdictions of management authorities, are often regarded as neither land nor sea and are consequently excluded from both river and coastal management (Attwood et al., 1997). In order to be effective, estuarine management should aim for best practices, which should be based on a sound understanding of estuarine functioning and guided by decision-making protocols on the use and care of estuaries (Boyd et al., 2000; Van Niekerk and Taljaard, 2003).

In the late 1970s there was considerable debate about whether or not the Bot River Estuary (also known as the Botvlei) was naturally turning into a freshwater coastal lake and whether or not the mouth should be artificially opened (Bally and Branch, 1986; Bally, 1987). An intensive six-year research programme followed, that mustered input from a range of disciplines and culminated in a symposium held in Cape Town during November 1983 where what in essence became the current management plan was drafted (Sloan et al., 1985). The estuary has since become recognised as a vital contributor in the minimum set of estuaries identified for the

* To whom all correspondence should be addressed.

唺+2721 808-3103; fax:+2721 808-3109; e-mail:JHVDM@sun.ac.za Received 29 October 2003; accepted in revised form 8 November 2004. preservation of estuarine biodiversity in South Africa (Turpie et al., 2002; Maree et al., 2003), bringing some new urgency to the need for a sound management plan.

This paper reviews past management practices and the data on which they were based. The paper also proposes future management options in the light of new findings.

\section{Study area and methods}

South Africa has 250 functional estuaries classified into five types: Estuarine bay, permanently open, river mouth, estuarine lake and temporarily open/closed (Whitfield, 1992; 1998). Permanently open systems constitute $19 \%$, while estuarine bays, estuarine lakes and river mouths constitute $1 \%, 3 \%$ and $5 \%$ of South African estuarine systems respectively (Maree et al., 2003). The majority (72\%) of South African estuaries are temporarily open/closed systems, which means that they are isolated from the sea by the formation of a sand berm across the mouth during periods of low or no river inflow (Maree et al., 2003). Such estuaries stay closed until their basins fill up and their berms are breached by increased river flow.

The Bot River Estuary is a relatively shallow (-1.5 m MSL) triangular temporarily open/closed estuarine lake, roughly $7 \mathrm{~km}$ long and about $2 \mathrm{~km}$ at its widest (Fig. 1) (Willis, 1985; Koop, 1982). It is located between $34^{\circ} 18^{\prime} 30^{\prime \prime}$ to $34^{\circ} 22^{\prime} 30^{\prime \prime} \mathrm{S}$ and $19^{\circ} 04^{\prime}$ ' to $19^{\circ} 09^{\prime} \mathrm{E}$ on the south-western coast of South Africa some $110 \mathrm{~km}$ south-east of Cape Town (Koop, 1982; Rogers, 1985).

The Bot Estuary mouth has in recent years been mostly closed (or "blind"), since it is cut off from the sea by a berm and an adjacent belt of coastal dunes. The valleys between the dunes are sufficiently low in some places to permit occasional wave overtopping from the sea during exceptionally high tides. The coastal dune belt is shifting landward due to the deliberate stabilisation projects through the introduction of mainly Acacia cyclops since the 1940s (Bally, 1985). The Bot and Kleinmond Estuaries are connected via a natural overflow channel at a water level of approximately $1.7 \mathrm{~m} \mathrm{MSL}$ through the Lamloch swamps and in the dune slacks (Branch et al., 


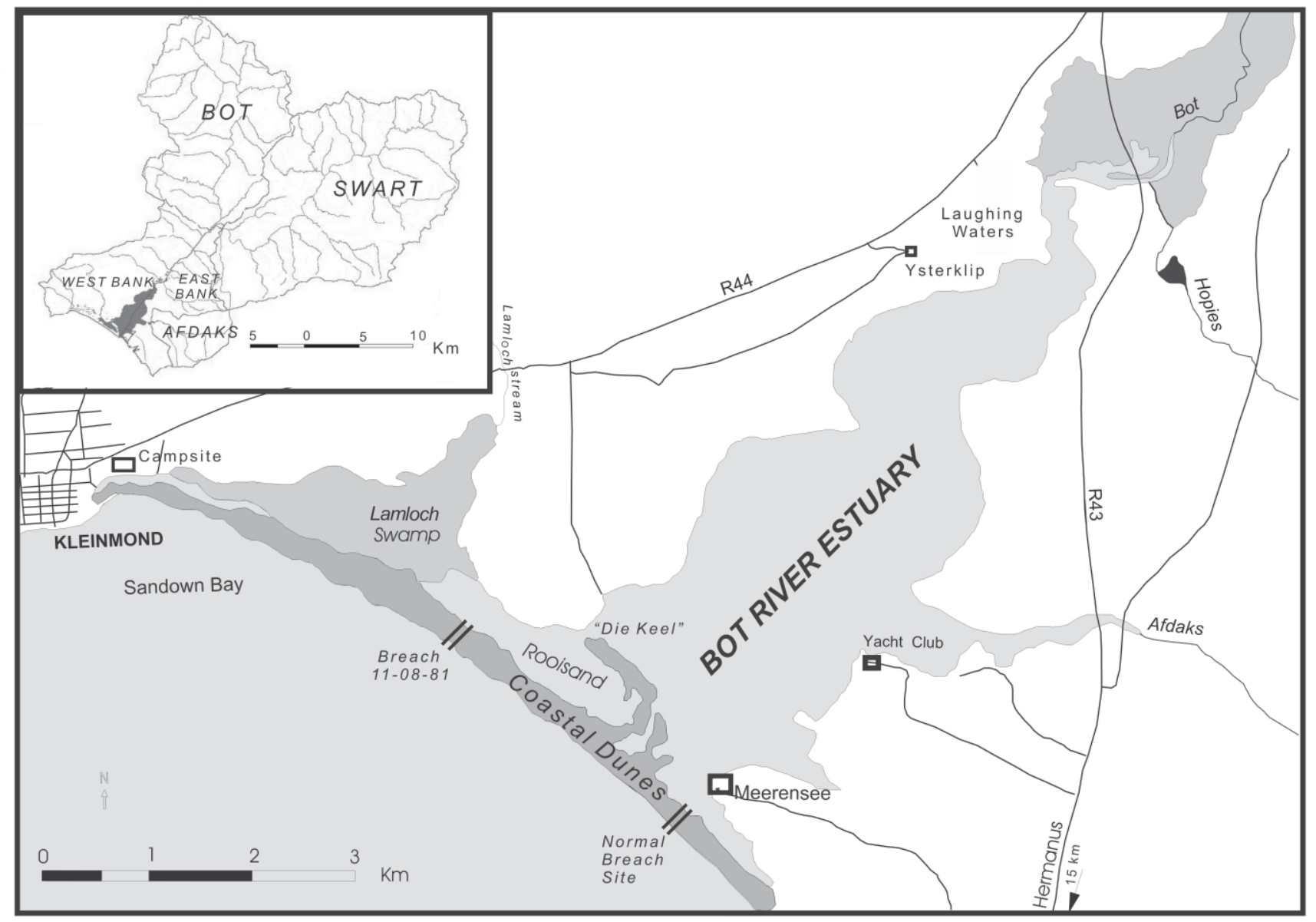

Figure 1

The Bot River Estuary and its catchment

1985; Bally, 1987; Koop, 1982; Van Heerden, 1985) (Fig. 1).

This paper reviews the hydrodynamics of the Bot Estuary through a combination of newly generated data and a re-evaluation of past findings. Revised mean annual runoff (MAR) estimates were provided by the Department of Water Affairs and Forestry (DWAF) and V3 Consulting Engineers (2000), after which these revised estimates were compared to measured inflow at the Roode Heuvel gauging station (G4H014-A01). Bathymetric data were used in a volumetric and area analysis of the Bot Estuary. Recorded estuary water-level data (for 20 years) were evaluated to get a better understanding of the hydrodynamics of the Bot Estuary. These new findings are then discussed in the context of the breaching of the Bot Estuary mouth, the water-level balance mechanism of the combined Bot/Kleinmond system and long-term salinity variation.

In the last 20 years estuarine management has shifted from preservation of estuaries in a predefined "desired state" to recognition of the natural dynamics and variability of systems, and enabling the ecological functions that depend on such variability (DWAF, 2002). This implies that management of the Bot Estuary should aim to encourage and re-establish natural fluctuations in water levels and salinities to be more consistent with natural drivers.

\section{Results and discussion}

Estuarine dynamics are governed by natural conditions and modified through human interference. The factors that are impacted on and which are dealt with here include, in sequence, runoff trends from the catchment, water level fluctuations in the estuary and chemical properties of the estuarine waters, all of which have ecological repercussions and may ultimately require management interventions.

\section{Catchment and runoff}

The total catchment size of the Bot River has been variously reported at $813 \mathrm{~km}^{2}$ (Heydorn and Tinley, 1980) and $1000 \mathrm{~km}^{2}$ (Caledon Divisional Council, 1975). However, an accurate demarcation of the five subcatchments demarcated using the catchment demarcation module in the ArcInfo geographical information system (GIS) from a 20 m resolution digital elevation model(DEM), showed this figure to be approximately $900 \mathrm{~km}^{2}$ (Table 1). Depending on the water level, the Bot Estuary covers a total area of between $9 \mathrm{~km}^{2}$ and $23 \mathrm{~km}^{2}$ (Branch et al., 1985) and was recently mapped at $13.6 \mathrm{~km}^{2}$ as reported in Table 1.

The MAR from these catchments has been variously estimated as being between $47 \times 10^{6} \mathrm{~m}^{3}$ (Jezewski and Roberts, 1986) and $116 \times 10^{6} \mathrm{~m}^{3}$ (Noble and Hemens, 1978). V3 Consulting Engineers (2000) recently adjusted this figure for virgin MAR to $86 \times 10^{6} \mathrm{~m}^{3}$. It should be noted that the latter figure included the sub-catchments of the Bot, Swart and the Afdaks Rivers only (see Fig. 1). It excluded runoff from the smaller tributaries and the surrounding mountains directly into the estuary across the lower western and eastern shores. The Water Situation Assessment Model (WSAM) (Schultz and Watson, 2002) provided a similar estimate of $88.54 \times 10^{6} \mathrm{~m}^{3}$ for virgin MAR and $65.9 \times 10^{6} \mathrm{~m}^{3}$ for present-day MAR (Table 1; Roberts, 2002). 
TABLE1

Land cover and estimated runoff for Bot River subcatchments

\begin{tabular}{|c|c|c|c|c|c|c|c|c|}
\hline \multirow[b]{2}{*}{ Land-cover class } & \multicolumn{7}{|c|}{ Area per subcatchment (ha) } & \multirow{2}{*}{$\begin{array}{l}\% \text { of } \\
\text { Total } \\
\text { catch- } \\
\text { ment }\end{array}$} \\
\hline & $\begin{array}{l}\text { Bot } \\
\text { River }\end{array}$ & $\begin{array}{l}\text { Swart } \\
\text { River }\end{array}$ & $\begin{array}{l}\text { Afdaks } \\
\text { River }\end{array}$ & $\begin{array}{c}\text { Lower } \\
\text { East } \\
\text { bank }\end{array}$ & $\begin{array}{c}\text { Lower } \\
\text { West } \\
\text { bank }\end{array}$ & Botvlei & TOTAL & \\
\hline Urban built-up (town) & 171 & 261 & 16 & 298 & 273 & - & 1018 & 1.1 \\
\hline Other built-up & 30 & 126 & 13 & 168 & 219 & - & 555 & 0.6 \\
\hline Road surface (all classes) & 196 & 370 & 24 & 73 & 105 & - & 767 & 0.8 \\
\hline Annual agriculture (cereals/grazing) & 8611 & 27448 & 592 & 2071 & 1210 & - & 39931 & 44.0 \\
\hline Perennial agriculture (orchard, vineyard) & 445 & - & - & - & 1744 & - & 2190 & 2.4 \\
\hline Forestry plantation & 1286 & 717 & 284 & - & 171 & - & 2459 & 2.7 \\
\hline Cultivated fynbos & - & - & - & - & 205 & - & 205 & 0.2 \\
\hline Natural fynbos & 14697 & 9315 & 2459 & 1716 & 4347 & - & 32534 & 35.9 \\
\hline Sparse alien vegetation & 54 & 81 & 97 & 660 & 776 & - & 1669 & 1.8 \\
\hline Dense alien vegetation & 490 & 650 & 279 & 479 & 583 & - & 2481 & 2.7 \\
\hline Water surface: Dams & 140 & 111 & 29 & 25 & 81 & - & 387 & 0.4 \\
\hline Water surface: Estuary & - & - & - & - & - & 1359 & 1359 & 1.5 \\
\hline River course & 66 & 147 & 20 & 56 & 45 & - & 332 & 0.4 \\
\hline Wetland & - & - & - & - & 306 & - & 306 & 0.3 \\
\hline Bare rock (mountainous) & - & 2807 & - & 640 & 390 & - & 3837 & 4.2 \\
\hline Other bare surface (beach, excavations) & 87 & 158 & 33 & 86 & 330 & - & 694 & 0.8 \\
\hline Total Bot River catchment area (ha) & 26273 & 42192 & 3847 & 6270 & 10785 & 1359 & 90726 & 100.0 \\
\hline$\%$ of Total catchment & 29.0 & 46.5 & 4.2 & 6.9 & 11.9 & 1.5 & 100.0 & \\
\hline Estimated virgin runoff $\left(10^{6} \mathrm{~m}^{3}\right)$ & 37.22 & 21.65 & 29.67 & $?$ & ? & ? & 88.54 & \\
\hline Estimated current runoff $\left(10^{6} \mathrm{~m}^{3}\right)$ & 24.78 & 18.70 & 23.7 & ? & ? & ? & 65.9 & \\
\hline
\end{tabular}

A number of intervention factors influenced the calculated $25.6 \%$ reduction in MAR from the virgin situation to the present. A full $44 \%$ of the catchment has been ploughed under for cereal production, mainly to replace South West Coast Renosterveld fynbos. Alien forestation (mainly pine species) in the Bot catchment (nearly 2500 ha) and alien vegetation infestations (mainly Acacia species, covering over 4000 ha or $4.5 \%$ of the catchment area) in the lower reaches and along the river courses play major roles. Various irrigation practices in upstream locations (especially $>2000$ ha fruit cultivation in the main Bot Valley) and evaporation from irrigation dams and directly from rivers and the estuary (in total $>2000$ ha) make increasingly heavy water demands. Significantly, a mere $43 \%$ of the total catchment is relatively free of human intervention in terms of the current land use pattern - the rest has been totally altered.

Table 2 does not reflect this tendency in the total and monthly average flow rate for DWAF river gauging station G4H014-A01 at Roode Heuvel that represents approximately $29 \%$ of the Bot River catchment, for the 33-year period from 1966. The tabled figures exclude the Swart and Afdaks Rivers and the direct flows to the estuary. The average annual runoff flow rate during this period was $0.69 \mathrm{~m}^{3} / \mathrm{s}$ or $21.78 \times 10^{6} \mathrm{~m}^{3}$, a somewhat lower value than the WSAM prediction of $24.8 \times 10^{6} \mathrm{~m}^{3}$ (see Table 1). The random distribution of peaks and troughs in runoff and the lack of recognisable trends in running averages throughout the period showed no signs of systematic reduction or increase in catchment water production. Since most of the land-use changes that had a permanent impact on the catchment had already taken place before the 1970s it is realistic to assume that the decline in runoff from the virgin condition had already occurred prior to this recording period. With the exception of the mountains in the north and south-east of the catchment, the landscape previously covered by fynbos has been almost universally ploughed under for cereal production or deciduous fruit cultivation.

Two measures of variability demonstrate the nature of runoff at Roode Heuvel gauging station: The standard deviation of 12.3 from the average and the range of $4.6 \times 10^{6} \mathrm{~m}^{3}$ to $53.3 \times 10^{6} \mathrm{~m}^{3}$ in annual total runoff. These figures indicate that variability in runoff may result in longer or shorter periods when runoff will be insufficient to produce a natural breaching of the estuary mouth. The trend in monthly runoff confirms the catchment's location in a winter rainfall area (Koop, 1982), with sharp discharge peaks in the winter months of July and August, that taper off to extreme lows by March.

\section{Bathymetry}

Using standard surveying techniques (Taljaard et al., 1999), the CSIR surveyed the bathymetry of the Bot Estuary and mouth in 1999. Depth soundings by echo sounder and a differential global positioning system (D-GPS), calibrated to official survey beacons, 
TABLE2

Monthly average flow rate $\left(\mathrm{m}^{3} / \mathrm{s}\right)$ for station G4H014-A01, Roode Heuvel in the Bot River

\begin{tabular}{|c|c|c|c|c|c|c|c|c|c|c|c|c|c|c|}
\hline Year & Oct & Nov & Dec & Jan & Feb & Mar & Apr & May & Jun & Jul & Aug & Sep & Avg & $\begin{array}{l}\text { Total vol } \\
\times 10^{6} \mathrm{~m}^{3}\end{array}$ \\
\hline $1966 / 1967$ & & & & & & & $0.293^{*}$ & 0.686 & 1.910 & 1.130 & 1.630 & 0.520 & & \\
\hline $1967 / 1968$ & 0.558 & 0.116 & 0.028 & 0.011 & 0.018 & 0.015 & 0.037 & 0.103 & 1.550 & 0.818 & 1.450 & 0.584 & 0.441 & 13.907 \\
\hline 1968/1969 & 0.369 & 0.099 & 0.013 & 0.012 & 0.023 & 0.023 & 0.041 & 0.054 & 0.123 & 0.177 & 0.216 & 0.609 & 0.147 & 4.636 \\
\hline 1969/1970 & 0.472 & 0.107 & 0.016 & 0.008 & 0.041 & 0.022 & 0.029 & 0.073 & 0.135 & 0.614 & 1.210 & 1.260 & 0.333 & 10.501 \\
\hline $1970 / 1971$ & 0.524 & 0.087 & 0.050 & 0.020 & 0.013 & 0.023 & 0.027 & 0.086 & 0.101 & 1.200 & 1.660 & 0.783 & 0.381 & 12.015 \\
\hline $1972 / 1973$ & 0.184 & 0.034 & 0.004 & 0.005 & 0.009 & 0.005 & $0.010^{*}$ & 0.048 & 0.039 & 0.078 & 1.130 & 0.364 & 0.159 & 5.014 \\
\hline 1973/1974 & 0.173 & 0.011 & 0.000 & 0.000 & 0.000 & 0.005 & 0.002 & 0.059 & 0.234 & 0.081 & 10.100 & 2.770 & 1.120 & 35.320 \\
\hline $1974 / 1975$ & 0.733 & 0.408 & 0.039 & 0.007 & 0.006 & 0.016 & 0.037 & 0.206 & 0.202 & 1.210 & 2.470 & 0.747 & 0.507 & 15.989 \\
\hline $1975 / 1976$ & 0.428 & 0.137 & 0.038 & 0.001 & 0.000 & 0.015 & 0.025 & 0.093 & 2.100 & 1.930 & 1.310 & 0.552 & 0.553 & 17.439 \\
\hline 1976/1977 & 1.030 & 1.200 & 0.421 & 0.069 & 0.129 & 0.081 & 0.515 & 1.640 & 3.910 & 5.320 & 4.790 & 1.130 & 1.690 & 53.296 \\
\hline $1977 / 1978$ & 0.468 & 0.185 & 0.251 & 0.058 & 0.026 & 0.042 & 0.135 & 0.105 & 0.119 & 0.651 & 1.350 & 1.330 & 0.394 & 12.425 \\
\hline 1978/1979 & 0.856 & 0.380 & 0.066 & 0.016 & 0.046 & 0.122 & 0.049 & 0.463 & 1.870 & 0.999 & 1.120 & 0.528 & 0.543 & 17.124 \\
\hline $1979 / 1980$ & 1.000 & 0.273 & 0.033 & 0.022 & 0.011 & 0.005 & 0.052 & 0.091 & 0.628 & 0.683 & 0.613 & 0.358 & 0.314 & 9.902 \\
\hline $1981 / 1982$ & 0.726 & 0.176 & 0.069 & 0.028 & 0.017 & 0.019 & 0.280 & 0.229 & 0.268 & 0.748 & 0.342 & 0.589 & 0.291 & 9.177 \\
\hline $1982 / 1983$ & 0.132 & 0.035 & 0.007 & 0.005 & 0.011 & 0.013 & 0.005 & 1.120 & 2.460 & 4.390 & 1.550 & 1.520 & 0.936 & 29.518 \\
\hline 1983/1984 & 0.911 & 0.135 & 0.042 & 0.012 & 0.007 & 0.010 & 0.040 & 3.600 & 0.537 & 1.150 & 0.660 & 1.980 & 0.757 & 23.873 \\
\hline $1984 / 1985$ & 1.700 & 0.256 & 0.333 & 0.228 & 0.251 & 0.530 & 0.404 & 0.280 & 0.631 & 4.550 & 2.160 & 0.476 & 0.984 & 31.031 \\
\hline 1985/1986 & 0.400 & 0.473 & 0.161 & 0.040 & 0.030 & $0.047^{*}$ & 0.153 & 0.131 & 0.370 & 0.667 & 6.700 & 2.280 & 0.954 & 30.085 \\
\hline 1986/1987 & 0.676 & 0.310 & 0.059 & 0.019 & 0.019 & 0.017 & 0.191 & 0.598 & 1.260 & 0.780 & 1.810 & 1.010 & 0.562 & 17.723 \\
\hline 1987/1988 & 0.515 & 0.073 & 0.019 & 0.013 & 0.007 & 0.010 & 0.080 & 0.099 & 0.564 & 0.709 & 0.428 & 1.250 & 0.314 & 9.902 \\
\hline 1988/1989 & 0.259 & 0.063 & 0.011 & 0.005 & 0.004 & 0.040 & 2.400 & 0.590 & 2.690 & 2.050 & 2.990 & 3.680 & 1.230 & 38.789 \\
\hline 1989/1990 & 1.410 & 0.574 & 0.119 & 0.024 & 0.121 & 0.101 & 0.262 & 1.130 & 2.290 & $1.95^{*}$ & 1.310 & 0.528 & 0.818 & 25.796 \\
\hline $1990 / 1991$ & $0.263^{*}$ & $0.080 *$ & 0.050 & 0.024 & 0.023 & 0.028 & 0.049 & 0.112 & 0.956 & 3.150 & 2.240 & 1.110 & 0.674 & 21.255 \\
\hline 1991/1992 & 1.370 & 0.896 & 0.110 & 0.031 & 0.026 & 0.054 & 0.155 & 0.333 & 2.170 & 1.980 & 1.330 & 1.860 & 0.860 & 27.121 \\
\hline $1992 / 1993$ & 2.080 & 0.725 & 0.152 & 0.069 & 0.099 & 0.076 & 4.070 & 0.815 & 2.160 & 6.510 & $2.27 *$ & 0.670 & 1.640 & 51.719 \\
\hline $1993 / 1994$ & 0.315 & 0.133 & 0.126 & 0.064 & 0.088 & 0.094 & 0.110 & 0.183 & 3.050 & 2.490 & 1.100 & 0.486 & 0.687 & 21.665 \\
\hline $1994 / 1995$ & 0.193* & $0.062 *$ & 0.101 & 0.059 & 0.040 & 0.071 & 0.101 & 0.481 & 0.650 & 1.520 & 2.490 & 0.672 & 0.536 & 16.903 \\
\hline $1995 / 1996$ & 0.744 & 0.284 & 0.715 & 0.292 & 0.102 & $0.054 *$ & $0.082 *$ & 0.104 & $1.48 *$ & 3.070 & 1.160 & 1.040 & 0.761 & 23.999 \\
\hline 1996/1997 & 1.800 & 1.550 & 0.653 & 0.201 & 0.088 & 0.076 & 0.164 & 0.488 & 3.490 & 1.490 & 0.638 & 0.467 & 0.926 & 29.202 \\
\hline $1999 / 2000$ & 0.708 & 0.205 & 0.085 & 0.069 & 0.022 & 0.116 & 0.111 & 0.179 & 0.250 & $1.05^{*}$ & & & & \\
\hline Avg flow & 0.657 & 0.337 & 0.158 & 0.114 & 0.107 & 0.063 & 0.314 & 0.481 & 1.159 & 1.697 & 1.951 & 1.177 & 0.691 & 21.781 \\
\hline $\begin{array}{l}\text { Total vol } \\
\mathrm{x} 10^{6} \mathrm{~m}^{3}\end{array}$ & 20.7 & 10.6 & 5.0 & 3.6 & 3.4 & 2.0 & 9.9 & 15.2 & 36.6 & 53.5 & 61.5 & 37.1 & 21.78 & \\
\hline \multicolumn{15}{|c|}{ * Record incomplete; } \\
\hline
\end{tabular}

were fed into HydroPro navigational software to record the position and depth data. Survey accuracy to MSL was $0.01 \mathrm{~m}$ only. The survey was conducted during a period of mouth closure and in windless conditions (Vonk, 2000). The mapped result in Fig. 2 illustrates the relative shallowness of the estuary. A rather limited central area is deeper than -2.0 m MSL, but a large area is below MSL (the 0-m contour). There is a narrow outlet channel towards the mouth near Meerensee, where breaching is effected, as well as a shallow link or overflow channel towards the Kleinmond estuary in the west.

\section{Volumetric and area analysis}

Volumetric analysis normally serves to estimate the volume of water released during breaching. Such calculations were made for the neighbouring Klein River Estuary near Hermanus (Huizinga et al., 1997; Huizinga and Van Niekerk, 1998b; 1999). It also estimates the volume of water necessary to fill an estuary to a level where a morphologically efficient breaching is triggered that can scour an estuarine channel and mouth deep enough to prevent long-term sediment accumulation. Such calculations were also made for the Great Brak Estuary (The Great Brak River Environmental Committee (GEC), 1990) to assist with the management plan and to provide improved ecological conditions after breaching.

The 1999 data set was used to calculate the surface area of the estuarine water body as indicated in Fig. 3. As Fig. 2 shows, the data set used for the above calculation did not include the extended flooded area near the top of the estuary or at Rooisand. At 2.0 m MSL the area indicated in Fig. 3 is approximately $12.44 \mathrm{~km}^{2}$. Despite the shortcomings, the value compares well with Koop's (1982) estimates of $15 \mathrm{~km}^{2}\left(13.6 \mathrm{~km}^{2}\right.$ in the main lagoon and $1.28 \mathrm{~km}^{2}$ in the Rooisand area) under a normal closed condition with the water level at approximately $2.0 \mathrm{~m} \mathrm{MSL}$. The more important indicator is the calculation of the intertidal area, which is of great interest to ecologists to determine the extent of the available habitat to various (especially avian) life forms (Branch et al., 1985). The intertidal area of the estuary in an open state varies between 40 ha and 50 ha depending on the stage in the neap spring cycle and the duration since 


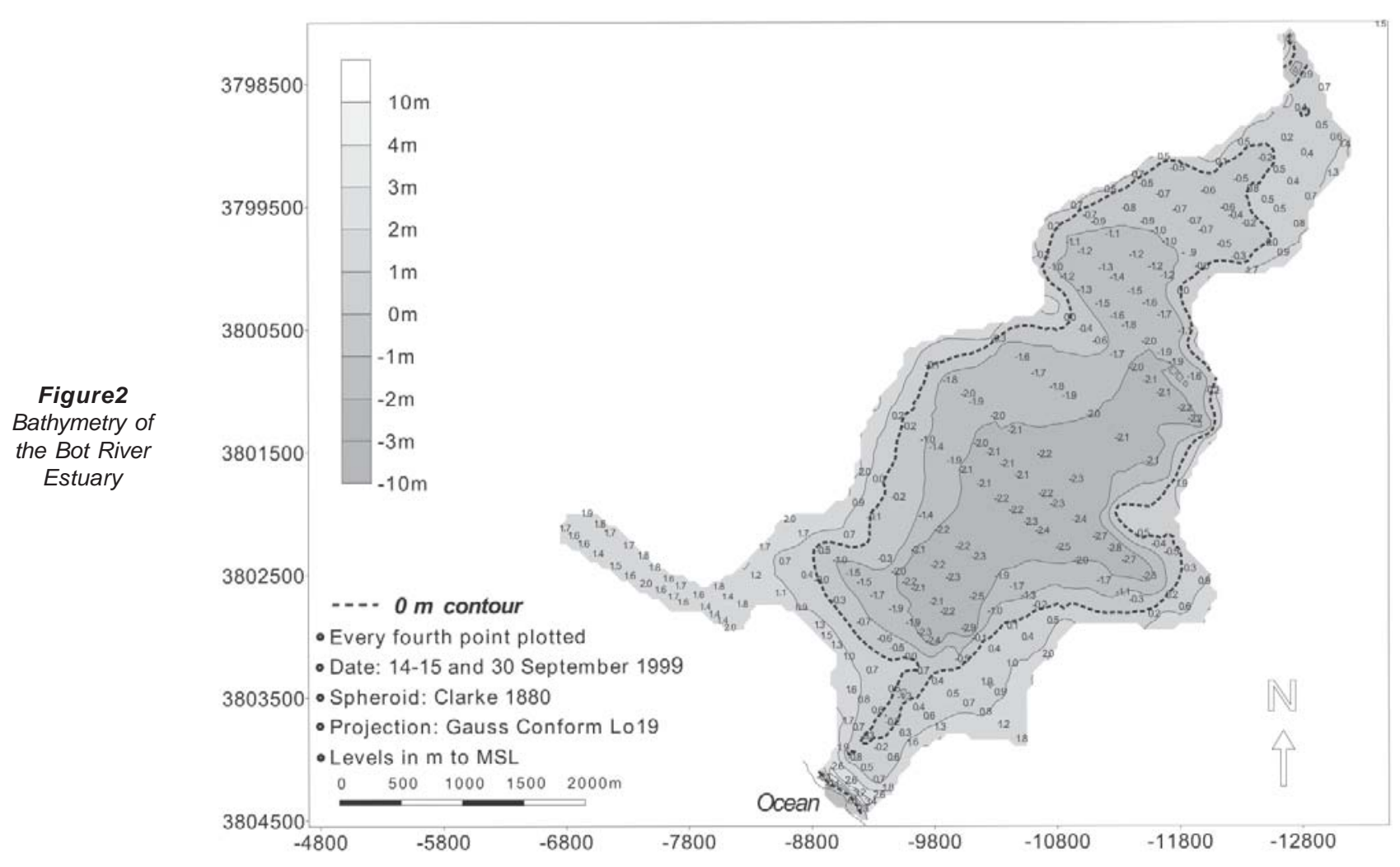

the last breaching. Continuous waterlevel recordings by DWAF show the estuary on average has a tidal amplitude of between 15 and $25 \mathrm{~cm}$ - typical for an estuarine lake with a large surface area and relatively small sea inlet.

With 1999 bathymetric data, Surfer for Windows GIS calculated the volume of the Bot Estuary as shown in Fig. 4. These estimates are accurate up to an estuary water level of $+2.0 \mathrm{~m}$ MSL, beyond which eccentricity in surface area introduces too much uncertainty in calculation. Around $3 \mathrm{~m}$ MSL the estuary volume is estimated at $45 \times 10^{6} \mathrm{~m}^{3}$ - about $50 \%$ the predicted virgin MAR and $70 \%$ the present day MAR. During a breaching event the water level in the Bot Estuary drops from its normal high level at about $2.75 \mathrm{~m}$ to around $0.0 \mathrm{~m}$ MSL in a few hours, to drain approximately $30 \times 10^{6}$ $\mathrm{m}^{3}$ of water from the system. Discounting evaporation, seepage through the berm and natural overflow losses to Kleinmond in the equation, one may conclude that the estuary needs nearly its full average annual runoff to fill to its full storage capacity. It can be deduced that the estuary has the potential to fill up and breach naturally during years of above average runoff, and that it may occur more often than is currently predicted. Other reasons must therefore account for the lack of natural breaching experienced in the recent past.

\section{Breaching of the Bot Estuary mouth}

At present the Bot Estuary is breached artificially approximately every two years. It was thought that it breached naturally only three times since 1940 (Bally and Branch, 1986). The Bot Estuary is normally breached at Meerensee (previously Sonesta) to create a tidal mouth between 80 and $110 \mathrm{~m}$ wide and $-2.0 \mathrm{~m}$ to $-2.5 \mathrm{~m}$ MSL deep. The estimates of the rate of outflow during breaching vary between $254 \mathrm{~m}^{3} / \mathrm{s}$ and $409 \mathrm{~m}^{3} / \mathrm{s}$ (Fromme, 1985a). The water level in the estuary ranges from around $+2.7 \mathrm{~m}$ MSL before breaching to just above or near MSL after the event (Koop, 1982). After

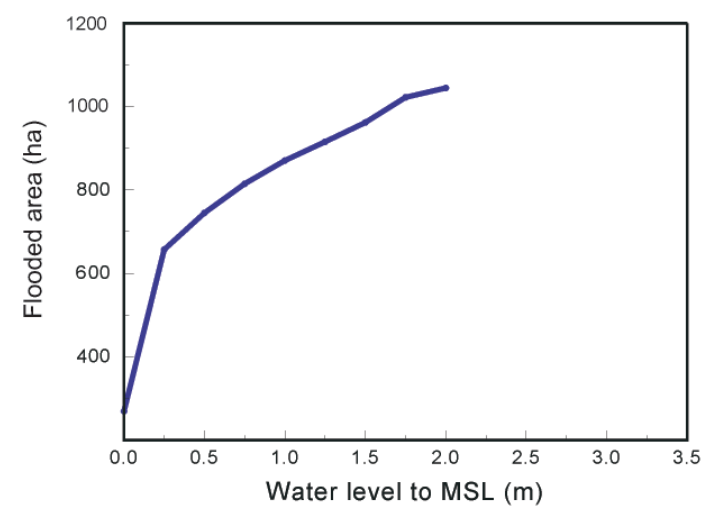

Figure3

Relationship between water level and area cover increase

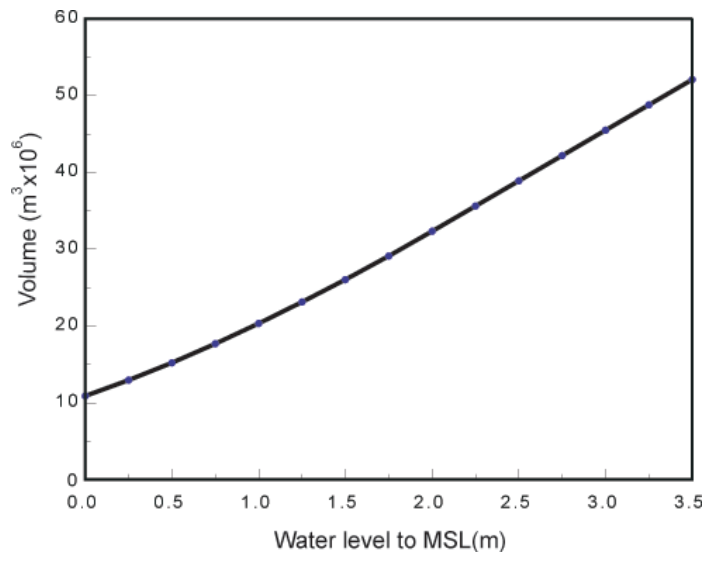

Figure 4

Relationship between water level and volume increase 


\begin{tabular}{|c|l|c|l|}
\hline \multicolumn{4}{|c|}{$\begin{array}{c}\text { TABLE3 } \\
\text { Summary of mouth breachings: 1979 - 2000 }\end{array}$} \\
\hline $\begin{array}{c}\text { Breach } \\
\text { No. }\end{array}$ & Date & $\begin{array}{c}\text { Duration } \\
\text { (months) }\end{array}$ & Trigger Event \\
\hline 1 & Aug 1981 & 2 & Flooding; low salinities \\
2 & Oct 1981 & 2 & Low salinities \\
3 & Jul 1983 & 4 & Flood \\
4 & Jul 1985 & 2.5 & Flood \\
5 & Aug 1986 & 5 & Flood; Natural breach \\
6 & Jun 1989 & 5.5 & Flood \\
7 & July 1990 & 5 & High water levels \\
8 & Apr 1993 & 5.5 & Flood \\
9 & Aug 1995 & 8 & High water levels \\
10 & May 1998 & 2 & Low salinities; High water levels \\
11 & Sept 2000 & 4 & Low salinities; High water levels \\
& & Average: 4 & \\
\hline
\end{tabular}

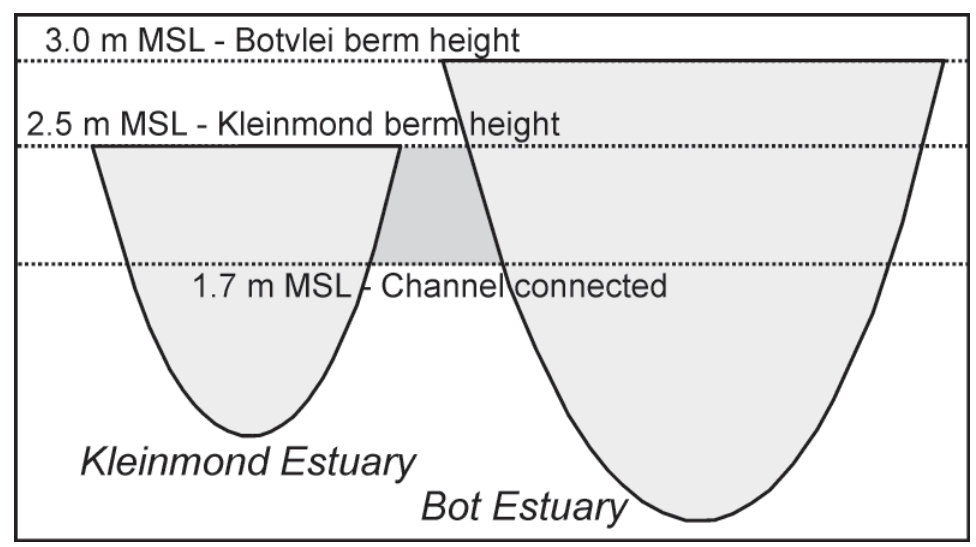

Figure 5

Schematic illustration of the import water levels at which the Bot and Kleinmond Estuaries interact

breaching, seawater intrusion into the estuary raises salinity to $35000 \mathrm{mg} / \ell$ throughout the estuarine water body (Bally and McQuaid, 1985; Willis, 1985).

Table 3 is based on water-level recordings in the Bot Estuary. It accurately summarises the occurrences of mouth breaching of the Bot Estuary during the recent 20-year period and lists the duration of the period the mouth remained open and the reasons for breaching. According to Bally (1985), only three natural breachings (in the early 1950s, 1977 and 1986 (Fig. 6)) were recorded with certainty since the 1940s. Of the ten breachings between 1979 and 1999 nine were effected by human intervention as part of the existing management plan. These breachings were either justified by high water levels (and thus an emulation of natural breach events) or to alter salinity conditions that were becoming detrimental to aquatic life in the estuary. On average the mouth remained open for four months after breaching.

When the joint system is breached at the Kleinmond Estuary mouth, the Bot Estuary loses, depending on the water levels, about $310000 \mathrm{~m}^{3}$ of water a day. Its surface level drops approximately $110 \mathrm{~mm}$ per week at high water levels (Willis, 1985). The Kleinmond Estuary is breached up to six times a year, mostly artificially. Such breaching can drain up to 1 m of water from the Bot Estuary - a critical loss that prohibits natural breaching of the Bot Estuary itself. In the absence of such incidences at Kleinmond, the Bot Estuary could breach naturally far more frequently. The loss of water has led to longer intervals between natural breachings of the Bot Estuary and to the present estuarine environment that reflects a system that is more freshwater defined. In the past this situation led scientists to assume that the Bot Estuary was developing naturally into a freshwater coastal lake-that in fact "the estuary is reaching the end-stage of its life as an estuary” (Branch et al., 1985:469).

Previous studies described breaching (natural or artificial) as a major catastrophe in the life cycle of the system due to the consequent drastic changes in salinity, water levels and exposure of the marginal areas (Branch et al., 1985; Morant and Quinn, 1999). However, these studies ignored the positive long-term post-breaching benefits of a system that functions near to its natural or reference condition; namely an exposed inter-tidal zone, a more saline water column, marine connectivity, and resuspension and flushing of sediment from the estuary. Current approaches to estuarine research emphasise the need for systems to be evaluated in terms of change from the reference condition to their present state. Original, natural (or "reference") conditions are taken as the state to which the system should be managed (Huizinga and Van Niekerk, 1997; 1998a; 1998c; 1998d; 1998e; DWAF, 2002). This approach, which requires an evaluation of all the factors that influence the Bot/Kleinmond interaction to determine its reference state, was not previously followed in analysing the system.

\section{The water-level balance mechanism}

The water level in the estuary depends on the balance between inflow (+) and outflow (-). The inflow depends on catchment runoff and the outflow on losses through the Kleinmond mouth, seepage and evaporation. Figure 5 illustrates this balancing mechanism in the three crucial berm elements that control water levels in the Bot Estuary.

- The Bot and Kleinmond Estuaries connect at the estimated level of 1.7 m MSL (Koop, 1982);

- The Kleinmond Estuary mouth breaches naturally at $2.5 \mathrm{~m}$ MSL - the berm level observed during a natural breaching event in 2000 in the absence of human intervention (Martens, 2001);

- Thenatural breaching level of Botvlei varies between 2.7 m MSL (Koop, 1982) and 3.0 m MSL (Van Niekerk et al., 2000).

The interaction between the two systems begins via the connecting outflow channel at a water level of about $1.7 \mathrm{~m}$ MSL. With the Kleinmond Estuary open, water is lost to sea via the Kleinmond mouth. The Bot Estuary breaches naturally only when river inflow exceeds the latter outflow. The total inflow volume required for its breaching is thus largely determined by the Kleinmond losses. Increased losses through the Kleinmond mouth increases the peakedness of floods or extent of freshwater inflow required for the Bot Estuary to breach naturally. Therefore premature opening at Kleinmond, in addition to the reduced runoff, critically reduces the expected frequency of natural breaching events at Botvlei under natural conditions. 
Water-level analysis

DWAF maintains an uncorrected water-level recorder (G4R003) in the Botvlei, which is not referred to mean sealevel(MSL). It collects continuous data on tidal variation and provides essential information on mouth closure in the estuary. Based on the readings from the gauge plate near the mouth, from which the MSL level was established, $0.6 \mathrm{~m}$ needs to be subtracted from the water-level recordings to reduce these readings to MSL. Fig. 6 shows the waterlevel recordings reduced to MSL, and illustrates the water-levelfluctuation in the estuary for the 20year period from 1979 to 2000 . Significant flood and high-flow events are tagged on the figures to guide further discussion and comment. The ten breaching events and the consequent rapid and steep reduction in water level are also indicated. In each case, the trigger events were preceded by rising trends in the water level. It is especially important to note the additional occasions (11 in all) where the record indicates a clear potential for water-level build-up that may have led to a natural Bot Estuary breaching. The graph profiles in these cases show a gradual (normal winter runoff filling) or abrupt (flood event) rise in the water level interrupted by an equally abrupt, yet modest, decline in water level, that signals a breach at the Kleinmond mouth. The gradual drop in water level caused by a Kleinmond breaching is due to its limited draining capacity. In comparison, the abrupt and massive outflow profile drops after the recorded Bot Estuary breachings present a sharp and characteristic contrast.

Table 4 summarises actual and potential breaching years for the 20 -year period for which water level recordings undernaturalconditions (multiple breaching are allowed for in some years) are available. This information therefore indicates that mouth breaching could have occurred during most of these years, if artificial breaching had not been conducted at Kleinmond. This scenario would have been even more likely if the estimated $25 \%$ reduction in runoff from the catchment had not occurred.

It would only be possible to claim that the Bot River Estuary
1979
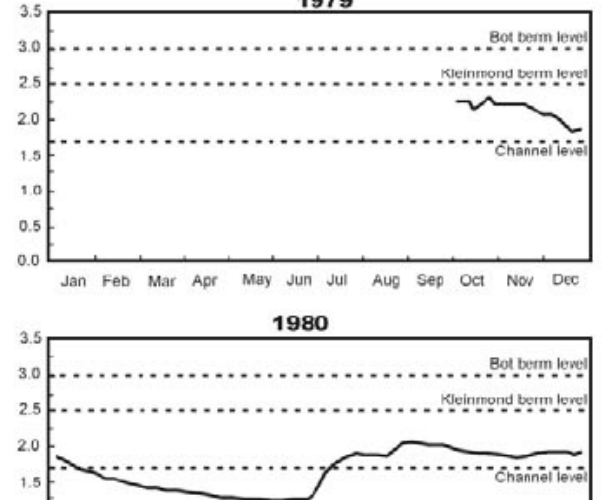

1.0
0.5

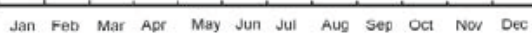

1981

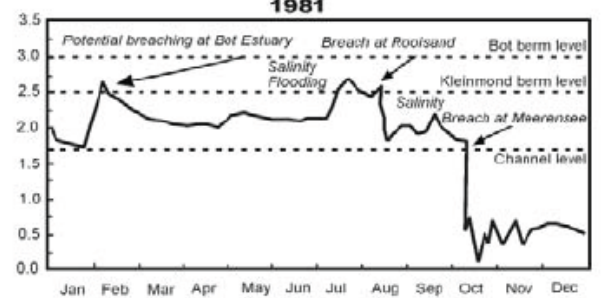

1982

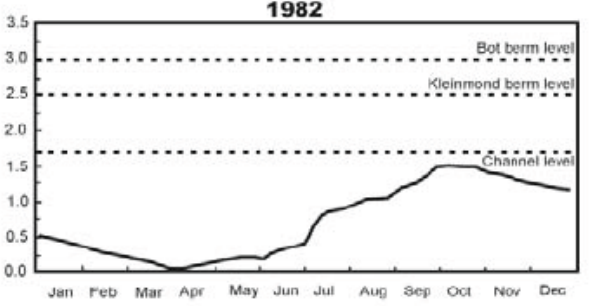

1983

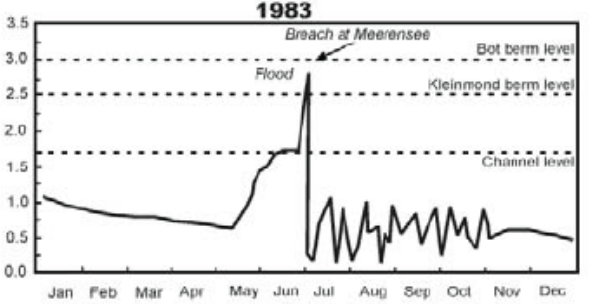

1984

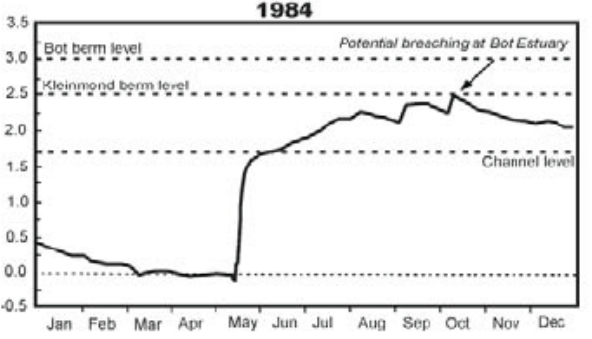

1985

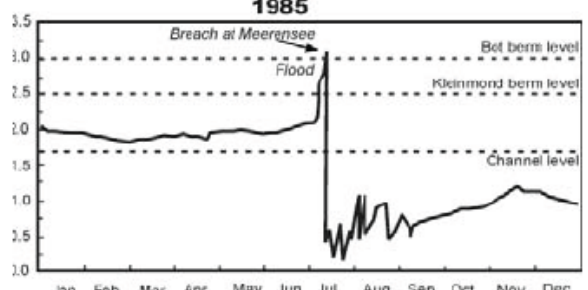

1986

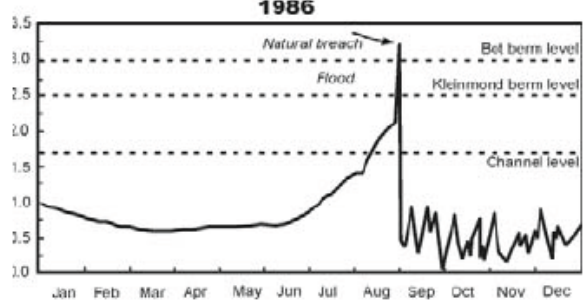

1987

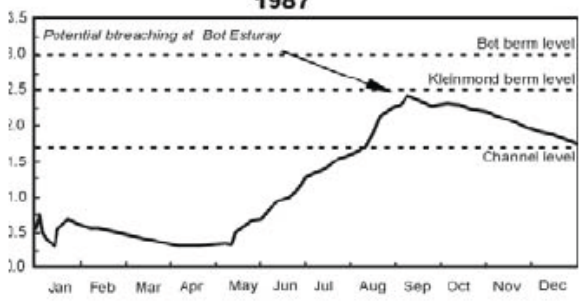

1988

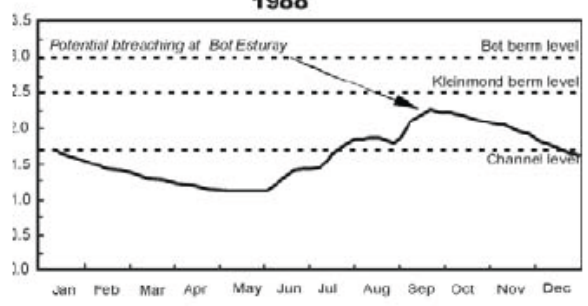

1989

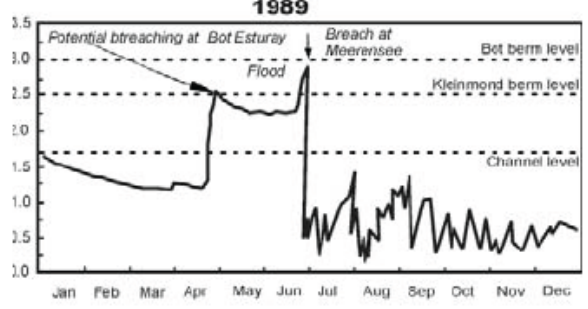

1990

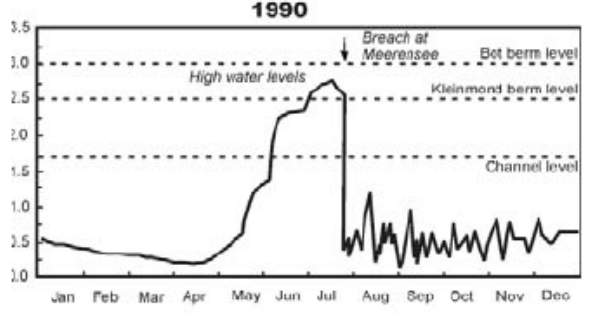

Figure 6 a

Bot River Estuary water levels from recorder G4R003 (1979-1990)

is becoming fresher naturally if there had not been reduced runoff from the catchment and if the Kleinmond breaching cycle had been unaffected by human intervention. This has clearly not been the case. In fact, the observations mentioned could substantiate a claim that the system may have been far more estuarine in nature without human intervention at the Kleinmond mouth and land-use changes in the catchment. 

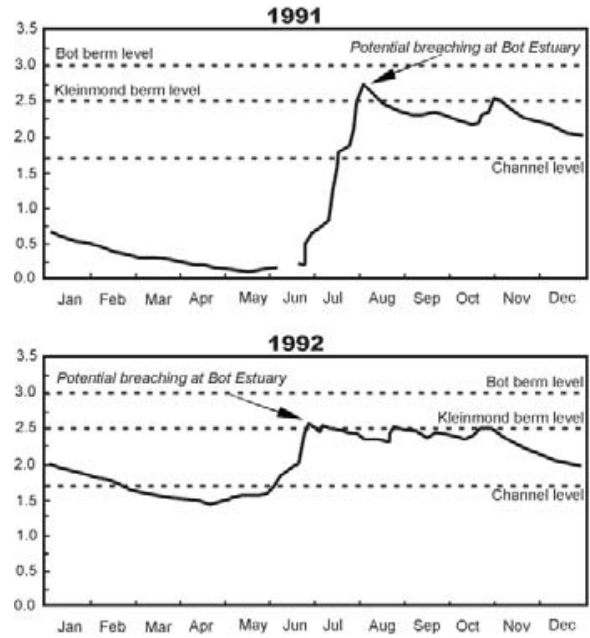

1993

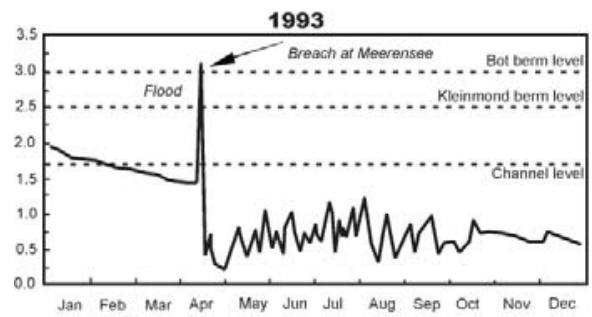

1994

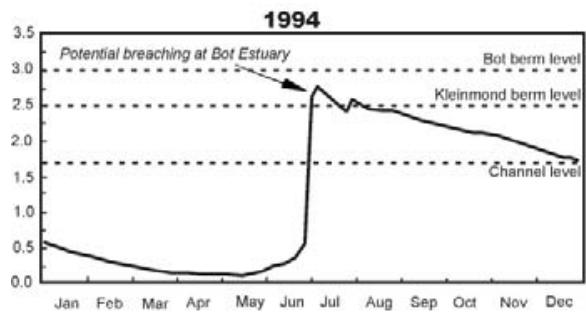

1995

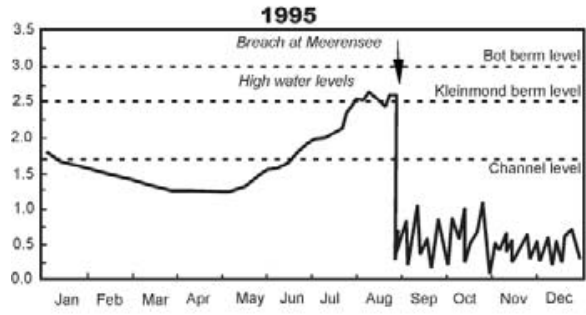

1996

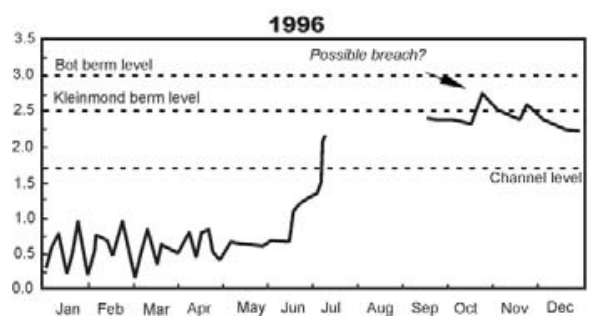

Salinity variation

Salinity in the Bot Estuary can vary from nearly fresh $(<1000$ $\mathrm{mg} / \ell$ ) to hyper saline ( $>35000 \mathrm{mg} / \ell$ ) depending on the stage in a four-state cycle (adapted from Bally (1987) and Bally and McQuaid (1985)) as depicted in Fig. 7.

After the mouth closes (State 1) and the water level remains low, the salinity in the system increases in summer due to evaporation to periodically rise to levels above that of sea water. A measurement of $47000 \mathrm{mg} / \ell$ has been recorded (Bally and McQuaid, 1985). The
1997

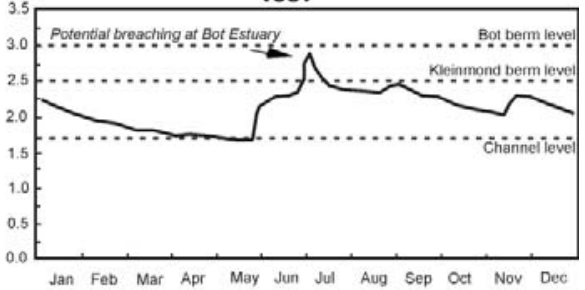

1998

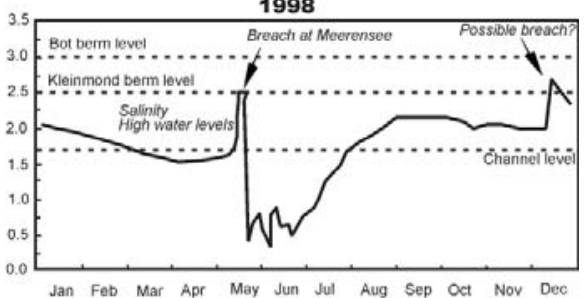

1999

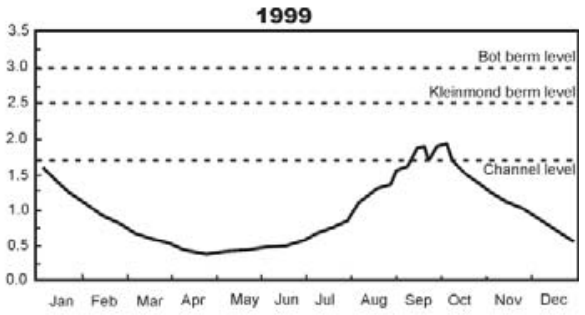

2000

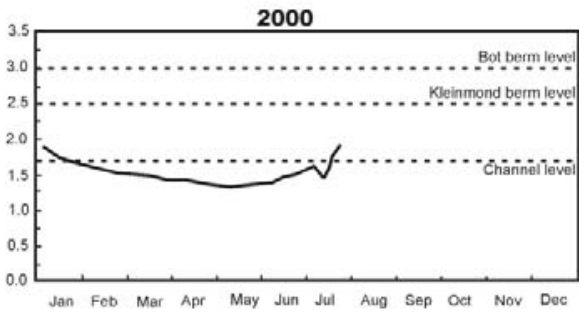

TABLE4

Potential natural breaching years of the Botvlei mouth: $1979-1999$

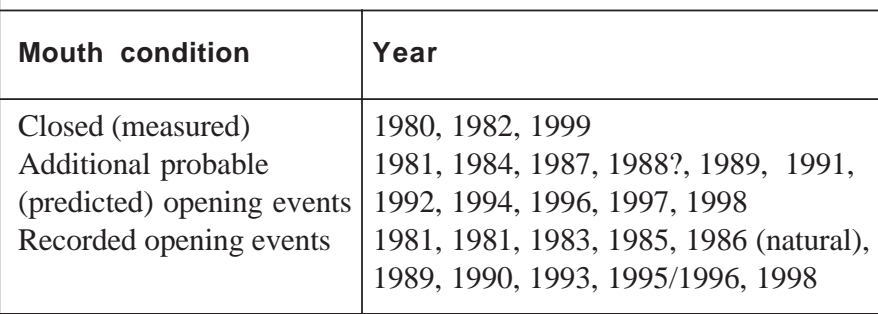

second state is entered with the start of the winter rains (State 2a), when, depending on the amount of rain, the water level rises and salinity decreases due to dilution. Should sufficient rain continue to fall (State 2b) - and this is conditional, since in some dry years (1980, 1982, 1999 in Fig. 6 offer examples) this state does not fully materialise - the estuary water level increases to about $1.7 \mathrm{~m}$ MSL when water overflows via the channel and the salinity in the Bot Estuary continues to drop further. This cyclical process is strongly influenced by the state of the Kleinmond mouth.

Should enough runoff continually enter the system (State 3), the 


\begin{tabular}{|c|}
\hline $\begin{array}{l}\text { 1. Mouth closes after breaching } \\
\text { Water level still low }(0.0-+0.8 \mathrm{~m} \mathrm{MSL}) \text { and salinity high; } \\
\text { Weed beds die; Birdlife diminishes; No recruitment } \\
\text { of juvenile fish or invertebrates; Fish stocks replenished; } \\
\text { Salinity increases during summer (evaporation) }\end{array}$ \\
\hline $\begin{array}{l}\text { 2a. Winter rains arrive } \\
\text { Water level rises and salinity declines; } \\
\text { Weed beds regrow slowly; Water fowl numbers } \\
\text { increase and wader birds decrease; Brackish to } \\
\text { freshwater fish species advantaged over estuarine fish } \\
\text { species, No migration of estuarine fish }\end{array}$ \\
\hline $\begin{array}{l}\text { 2b. More winter rain } \\
\text { Water overflows to Kleinmond via channel }(\sim 1.7 \mathrm{~m} \mathrm{MSL}) \text {; } \\
\text { Salinity declines; Mass fish mortalities if salinity }<6 \mathrm{ppt}\end{array}$ \\
\hline $\begin{array}{l}\text { 3. Estuary mouth breaches } \\
\text { Estuary drains to ocean; } \\
\text { Water level declines from } 3.0 \text { to between } 0.00 .8 \mathrm{~m} \text {; } \\
\text { MSL and saline water enters the mouth area; } \\
\text { Flushing of sediments and biota to sea, i.e. resetting of } \\
\text { estuarine habitat }\end{array}$ \\
\hline $\begin{array}{l}\text { 4. Mouth remains open for } \sim 4 \text { months } \\
\text { Water level remains at between } 0.00 .8 \mathrm{~m} \text { MSL } \\
\text { (tidal variation) and salinity increases (often to ocean } \\
\text { equivalent); } \\
\text { Die-back of weed beds, Recruitment of estuarine or } \\
\text { estuarine dependant juvenile fish and invertebrates; } \\
\text { Water fowl leave, Estuarine migrants and wader birds } \\
\text { able to feed on exposed banks }\end{array}$ \\
\hline
\end{tabular}

Figure 7

Cyclic water level and salinity regulating mechanism in the Bot Estuary

Bot Estuary mouth can breach (naturally or artificially) to drain estuary water into the sea. In these cases, the water level drops from $+3 \mathrm{~m}$ to about $0.4 \mathrm{~m}$ or even $0 \mathrm{~m}$ MSL within a few hours, after which the mouth stays open (State 4) for about four months on average and the salinities in the system can equate that of seawater. A more regulated breaching pattern at the Bot Estuary would prevent the system from becoming too fresh with extended periods of low State 2 salinity values ( $<15000 \mathrm{mg} / \ell$ ) for up to three years and longer. This would also prevent extreme variation in salinity, as is sometimes the case under the current breaching policy. More frequent breaching would decrease the fluctuation in salinities illustrated in Fig. 8.

According to the foregoing analyses and results the described situation probably simulates natural conditions more closely. Furthermore, this process may be emulated through a managed artificial breaching policy to produce more natural ecological conditions.

\section{Evaluation of past management practices}

The conservation importance of the Bot/Kleinmond system as an estuary was confirmed by two recent South African surveys. On ecological health and conservation status it was ranked $8^{\text {th }}$ overall (Turpie, 2002; Turpie et al., 2002) and for fish habitat $13^{\text {th }}$ overall (Maree et al., 2003). The Cape Action Plan for the Environment (CAPE) rated the system among the ten most important estuaries in the Western Cape Province in terms of biodiversity and in protection urgency (Prochazka and Griffiths, 2000).

This conservation status as an estuarine system raises the question of how best to achieve the conservation aims set. The spurt

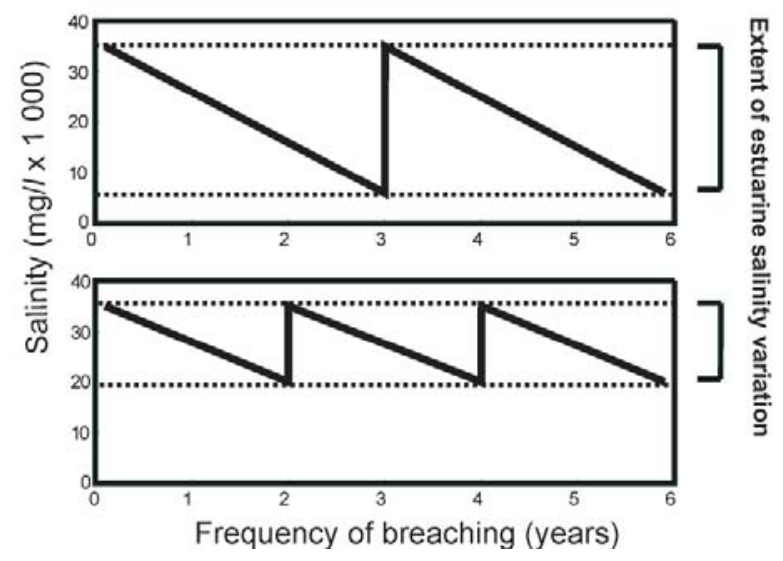

Figure 8

Relationship between breaching frequency and salinity range

of research in the early 1980s (Branch et al., 1985) offered the six management options summarised in Table 5 . These options were each designed to satisfy some (never all) user group requirements concerning the Bot River Estuary. Evaluated objectively, the first three options, which generally benefit environmental aesthetics and recreational users, would largely ensure a progression towards a permanent freshwater system with a change from an estuary into a freshwater coastal lake.

The continued development of the recently established multimillion rand Arabella golf estate on Botvlei's northern shore, which has already given rise to ecological controversy, is likely to provide renewed impetus to these options (Bonthuys, 2002a; 2002b). The developer needs consistent water levels to successfully market birdwatching and eco-tourism attractions. Therefore, an extended, consistent and predictable four-year breaching cycle is regarded as optimal, with breaching preferably in winter, to allow for efficient tourism planning and advertisement. While apparently reasonable, similar demands from developers along South African estuaries, instead of capitalising on the unique and diverse natures of our estuaries, could irreparably damage estuarine systems and compromise their survival as environmental resources.

Options 4-6 which allow continued breaching, would, depending on the frequency and timing of breachings, ensure continuance of the natural saline estuarine conditions that benefit estuarine fish and bird populations and hence the communities dependent on fishing for recreational or subsistence activities. The sixth option, as the one that effects the least change from the existing conditions and satisfies the greater number of interests, was clearly the most sustainable and environmentally compatible of the latter options and was adopted as the basis for the subsequent management practice.

The implementation of the suggested management policy had an inauspicious start. After an experimental breaching of the estuary at Rooisand in August 1981, the water level dropped without increasing salinities. This lead to mass fish mortalities (including all favourite angling species), and necessitated a further breaching at Meerensee (then Sonesta) by October of the same year. Until 1984 a strict policy of no breaching was followed, with results that failed to fully satisfy any of the four interest groups (Bally, 1987). The current management policy of regulated artificial breaching at Meerensee was only implemented from the middle 1980s, as is evident from Fig. 6. The question is whether current management practice has given effect to policy aims, or now needs re-evaluation 


\begin{tabular}{|c|c|c|}
\hline \multicolumn{3}{|c|}{$\begin{array}{c}\text { TABLE 5 } \\
\text { Management options for the Bot River Estuary }\end{array}$} \\
\hline Option & Implications (and effect) & \\
\hline $\begin{array}{l}\text { 1. Discontinue artificial breaching } \\
\text { (drift towards a freshwater } \\
\text { system) }\end{array}$ & $\begin{array}{l}\text { - } \text { Bot becomes a freshwater coastal lake } \\
\text { - } \text { No regular loss of plant and invertebrate life due to breaching } \\
\text { - } \text { Reduced salinity causes ecological change } \\
\text { - } \text { Some plant life will be replaced } \\
\text { - } \text { Exotic plants become established } \\
\text { - } \text { Sediment accumulates } \\
\text { - } \text { Decreased area for submerged weed growth } \\
\text { - Increase in freshwater insects } \\
\text { - } \text { Decrease in sand-prawn breeding } \\
\text { - } \text { Sea recruine and marine fish species die out } \\
\text { - } \text { Exotic freshwater fish specine fish species prevented } \\
\text { - Stable food supply for herbivorous birds } \\
\text { - } \text { Declining food supply for non-herbivorous birds } \\
\text { on freshwater habitat }\end{array}$ & $\begin{array}{r}(?) \\
(+) \\
(+?) \\
(-) \\
(+-) \\
(-) \\
(-) \\
(-) \\
(-) \\
(-) \\
(-) \\
(-) \\
(-) \\
(-) \\
(+) \\
(-) \\
(-)\end{array}$ \\
\hline $\begin{array}{l}\text { 2. Construct a weir at the mouth } \\
\text { (drift towards a freshwater } \\
\text { system) }\end{array}$ & $\begin{array}{l}\text { - Stabilise water level } \\
\text { - } \text { High construction cost } \\
\text { - } \text { No tidal penetration } \\
\text { - Sea recruitment of marine fish species prevented }\end{array}$ & $\begin{array}{l}(+) \\
(-) \\
(-) \\
(-) \\
(-)\end{array}$ \\
\hline $\begin{array}{l}\text { 3. Raise and fix dunes at the mouth } \\
\text { (drift towards a freshwater } \\
\text { system) }\end{array}$ & $\begin{array}{l}\text { - Same effects as } 1 \\
\text { - High cost of establishment and maintenance }\end{array}$ & $\begin{array}{l}(-) \\
(-)\end{array}$ \\
\hline $\begin{array}{l}\text { 4. Continue ad hoc breaching at } \\
\text { Meerensee(maintains an } \\
\text { estuarine system) }\end{array}$ & $\begin{array}{l}\text { - Safeguard properties from flooding } \\
\text { - 'Catastrophic' ecological effects continue } \\
\text { - Low species diversity } \\
\text { - } \text { Changes in aquatic plant life } \\
\text { Reduction of bird life }\end{array}$ & $\begin{array}{l}(+) \\
(-) \\
(-) \\
(-) \\
(-)\end{array}$ \\
\hline $\begin{array}{l}\text { 5. Raise "Die Keel" to prevent } \\
\text { overflow to Kleinmond } \\
\text { (maintains an estuarine system } \\
\text { if natural breaching occurs) }\end{array}$ & $\begin{array}{l}\text { - Higher water levels encourage natural breaching } \\
\text { - } \text { More frequent natural breaching of Bot } \\
\text { - } \text { Overflinity beneficial to estuarine life forms } \\
\text { - } \text { Diminished shallow area for weed growth in Bot } \\
\text { - Higher breaching intensity increases plant loss }\end{array}$ & $\begin{array}{l}(+) \\
(+) \\
(+) \\
(-) \\
(-) \\
(-)\end{array}$ \\
\hline $\begin{array}{l}\text { 6. Controlled breaching at } \\
\text { Meerensee(can maintain an } \\
\text { estuarine system depending on } \\
\text { the frequency and timing of } \\
\text { breaching) }\end{array}$ & $\begin{array}{l}\text { - System conditions remain estuarine } \\
\text { - Benefit marine and estuarine fish stock } \\
\text { - } \text { Benefit angling and fishing community } \\
\text { - } \text { Eliminatite watersity of rare wader bird communities } \\
\text { - Position, timing, frequency can be planned } \\
\text { - } \text { Seep, long-lasting mouth opening achieved } \\
\text { - Couring out of peak amounts of sediment } \\
\text { - } \text { Disrupt timing ensures recreational use in summer } \\
\text { - Introductionmond interconnection } \\
\text { - Exposure/drying out of macrophyte beds }\end{array}$ & $\begin{array}{l}(+) \\
(+) \\
(+) \\
(+) \\
(+) \\
(+) \\
(+) \\
(+) \\
(+) \\
(-) \\
(-) \\
(-)\end{array}$ \\
\hline
\end{tabular}

in the light of evolving approaches to estuarine management. The current management plan for the Bot Estuary, in following Option 6 guidance, stipulates that the mouth should be artificially breached only when the following combination of conditions prevail:

- The salinity level declines below $6000 \mathrm{mg} / \ell$ (compared to seawater at $35000 \mathrm{mg} / \ell$ ), threatening to cause fish mortality;

- There has been no breaching for three years - to ensure sufficient filling of the estuary and regrowth of the weed beds (dominated by Ruppia maritima and Potamogeton pectinatus in the upper reaches); and
- The water level rises above $2.5 \mathrm{~m}$ MSL - the required level to ensure a sufficiently large volume of water to efficiently scour silt from the mouth and to prevent flooding of a low-lying clubhouse.

The overall result of these policies is that the estuary is forced towards a more freshwater-dominated condition. This is despite abundant ecological evidence that the "natural" state of the system remains predominantly estuarine if the mouth does not remain closed for too long. For instance, the endemic Bot River Klipvis 
Clinus spatulatus, which prefers a more saline environment, still occurs, as does the sand prawn Callianassa kraussi, which stops breeding when salinity drops below 25000 mg/ / (Lamberth, 2001; Forbes, 1978).

The current management policy displays a lack of understanding of how the Kleinmond Estuary functions, and its effect on the Bot. Relevant literature shows that its influence on the Bot Estuary was largely disregarded during the previous round of policy formulation (Sloan et al., 1985; Fromme, 1985a). The decisions and management policy formulated then were not comprehensive enough and did not provide for the joint management of the two systems. The loss of water through the Kleinmond Estuary has led to longer breaching intervals, an increasingly freshwater-defined ecological system, and the erroneous scientific conclusion that the Bot Estuary is "naturally" developing into a freshwater coastal lake. As the analysis of the water levels here indicate, the system would have breached more often, if not for human intervention at the Kleinmond mouth and a general reduction in runoff from the catchment.

The advantages of more regular mouth breaching are more frequent connection with the marine environment, greater recruitment of estuarine and estuarine-dependent fish (Whitfield and Marais, 1999), the stabilisation of invertebrate communities, and prevention of extreme fluctuations in salinity. A more typical estuarine environment would in general increase the species diversity (Wooldridge, 1999; Whitfield and Marais, 1999). In fact, a Bot Estuary workshop in February 2003 (attended by 35 representatives of 16 interested and affected parties) isolated five natural system elements that would benefit from an active breaching policy that leads to more natural conditions: vegetation, sediment, estuarine birds, invertebrates and fish. Regarding vegetation, Phragmites australis reeds are prevalent in most freshwater systems in South Africa, sometimes due to increased nutrient loads from our catchments. Regular breaching of the Bot Estuary mouth would increase salinities to above $20000 \mathrm{mg} / \ell$ for longer than 3 months, restricting reed encroachment into shallows (Adams and Bate, 1999). Prolonged mouth closure would foster extensive Phragmites australis growth in the upper, shallower, section of the estuary, to trigger major estuarine habitat changes there. The reeds act as sediment traps, cause sediment deposition and a loss of water depth (Morant and Quinn, 1999). Furthermore, in the absence of regular estuary openings, non-cohesive sediments from high-flow events would remain trapped in the system, and cause slow in-channel and surrounding build-up. Elsewhere studies (e.g. Mhlatuze Estuary) have shown open-mouth conditions to allow re-suspension of sediment through tidal flows and wind mixing, and eventually transportation out to sea (Van Foreest, 1985; Huizinga and Van Niekerk, 1998d).

Bird densities are higher when mouth closure from September to December creates optimum conditions - mainly for water fowl (e.g. red-knobbed coot Fulica cristata) and piscivorous birds (e.g. white-breasted cormorant Phalacrocorax carbo) associated with freshwater systems. However, bird diversity is highest during openmouth phases (e.g. waders and tern species) and decreases during closed phases.

Invertebrates are negatively affected by infrequent breaching events, as it causes stop-start breeding patterns among species like the sand prawn Callianassa kraussi. Sand prawns cannot breed in salinities below $25000 \mathrm{mg} / \ell$ (Forbes, 1978), from which it may be inferred that infrequent mouth openings would reduce populations substantially. More frequent marine connection would encourage more regular recruitment, stable populations and higher densities. Estuarine-centred system management would generally increase species diversity (Wooldridge, 1999).
In combination, the Bot/Kleinmond and Klein Estuaries provide 40 to $50 \%$ of the estuarine nursery habitat for fish associated and dependent on estuaries along $350 \mathrm{~km}$ of coast from Cape Point to the Breede River Mouth (Lamberth and Turpie, 2003). The estuary is vital for 16 recreationally and commercially important species, such as white streenbras (Lithognathus lithognathus), leervis (Lichia amia) and dusky cob (Argyrosomus japonicus) (Bennett, 1985; Bennett et al., 1985; Lamberth and Turpie, 2003). Many of these species have an obligatory estuarine phase in their life cycle. The optimum period for open-mouth conditions and the recruitment of juvenile fish into the estuary is from August to December, which is in direct conflict with the closed conditions that waterfowl prefer. Current management practices have reduced fish abundance in the Bot Estuary to about $50 \%$ of that in the adjacent Klein Estuary. The logical assumption is that the Klein mirrors the Bot Estuary under reference conditions (Lamberth, 2001). In turn, the current management practice of restricting breaching to the winter season has allowed alien freshwater fish species, such as carp (Cyprinus carpio) and Mozambican tilapia (Oreochromis mossambicuis), to enter and compete with indigenous estuarine species. Ironically, more frequent breaching would allow many estuarine-dependent fish to escape before they grow large enough to become ensnared in the illegal gillnets that are used extensively throughout the estuary.

\section{Conclusions and recommendations}

The main conclusion is that anthropogenic interventions are responsible for the Bot Estuary's perceived shift from an estuarine system towards a freshwater coastal lake, and that it is not a natural phenomenon as was previously claimed. The Bot River Estuary will turn into a freshwater lake only if anthropogenic intervention at the Kleinmond Estuary mouth is continued and current land-use practices further reduce runoff from its catchment.

From this conclusion flows the recommendation to further verify and confirm the findings from this study. The relevant authorities are urged to:

- Conduct a Reserve study as required by the National Water Act (No. 36 of 1998) to assess more accurately the magnitude and nature of change in runoff from the catchment and the river flow required to maintain optimal system functioning

- Manage the Bot and Kleinmond Estuaries as an interconnected system, as Branch et al. (1985) recommended. The joint management plan should address the needs of both systems to ensure the survival of dependent species

- Prevent premature breaching at the Kleinmond mouth

- Address water-quality problems in the Kleinmond Estuary caused by sewerage overflow and leaking septic tanks to avoid breaching the estuary just to solve that problem

- Continuously monitor the berm heights of the Kleinmond and Bot Estuaries to determine the natural fluctuations in their heights

- Investigate the correlation between the flow from the Bot Estuary towards Kleinmond with the water levels in the Bot Estuary

- Continue DWAF monitoring of the water levels in the Bot and Kleinmond Estuaries. A continuous water level recorder has been operating at Kleinmond since early 2000 to establish the interactions between the two systems

- Continue monitoring by CapeNature (formerly Western Cape Nature Conservation Board) of the salinity in the Bot Estuary to get a clear understanding of the processes involved. The salinity at Kleinmond should be measured monthly to gain an insight into the flushing processes involved 
- Install accurate runoff gauge stations on the Swart and Afdaks Rivers to provide a full and reliably measured runoff scenario for the whole catchment, instead of having to rely on runoff modelling for these tributaries

- Adopt a balanced management strategy that prioritises maintenance of the ecological integrity of the system before it satisfies the sustainable requirements of interest groups that consume its resources. Management of the Bot Estuary by local authorities, according to local perspectives only, is not recommended. Its fish resources are of national importance and the custodianship of living marine resources lies with national government.

The criteria set out for breaching the Bot Estuary mouth still favour a shift from a valuable estuarine system towards a freshwater coastal lake. The breaching criteria need re-evaluation and adaptation to reverse the process and to promote natural estuarine conditions in the Bot Estuary.

Criteria for breaching the Bot Estuary should include any one of the following conditions:

- Salinities below $10000 \mathrm{mg} / \ell$ (or even $15000 \mathrm{mg} / \ell$ )

- No breaching for 2 years and water levels above 2.3 m MSL

- Water levels above $2.5 \mathrm{~m}$.

The Bot River Estuary lies in a region characterised by bitter and sometimes violent social division about access to, use of and conservation of natural marine and other environmental resources among several user communities from across the socio-economic spectrum. Long-term sustainability and the survival of sensitive habitats in this unique regional system will only be maintained through continued research, and the open sharing of management insight.

\section{Acknowledgements}

The authors acknowledge the Department of Water Affairs and Forestry, Hydrology Western Cape, for collecting and supplying the necessary data for this study, CapeNature, the Walker Bay Honorary Nature Conservation Officers and Marine and Coastal Management, Department of Environmental Affairs and Tourism for their assistance in monitoring the Bot River Estuary system. We gratefully recognise the valuable and constructive input into an earlier draft of this paper by two anonymous reviewers.

\section{References}

ADAMS JB and BATE GC (1999) Growth and photosynthetic performance of Phragmites australis in estuarine waters: A field and experimental evaluation. Aquat. Bot. 64 359-367.

ATTWOOD CG, HARRIS J and WILLIAMS A (1997) International experience of marine protected areas with relevance for South Africa. S. Afr. Network Coast. Ocean. Res. Occasional Report No. 2, 13-52.

BALLY R (1985) Historical records of the Bot River Estuarine system. Trans. R. Soc. S. Afr. 45 291-303.

BALLY R (1987) Conservation problems and management options in estuaries. The Bot River Estuary, South Africa, as a case-history for management of closed estuaries. Environ. Conserv. 14 (1) 45-51.

BALLY R and BRANCH G (1986) The Bot River Estuary - Should we interfere? Afr. Wildl. 40 (6) 230-239.

BALLY R and McQUAID CD (1985) The physical and chemical characteristics of the waters of the Bot River Estuary, South Africa. Trans. R. Soc. S. Afr. 45 317-331.

BENNETT BA (1985) A mass mortality of fish associated with low salinity conditions in the Bot River Estuary. Trans. R. Soc. S. Afr. 45 437-447.
BENNETT BA, HAMMAN KC, BRANCH GM and THORNE SC (1985) Change in the fish fauna of the Bot River Estuary in relation to opening and closure of the estuary mouth. Trans. R. Soc. S. Afr. 45 449-464.

BONTHUYS J (2002a) Hofstryd aan't broei oor bewaring in Kleinmond. Die Burger (24 October).

BONTHUYS J (2002b) Rooisand ontwikkeling 'bedreig nie biosfeer'. Die Burger (30 October).

BOYD AJ, BARWELL L and TALJAARD S (2000) Report on the National Estuaries Workshop. 3-5 May 2000, Port Elizabeth, South Africa. Report No. 2, Marine and Coastal Management Implementation Workshops. Cape Town: Chief Directorate Marine and Coastal Management.

BRANCH GM, BALLY R, BENNETT BA, DE DECKER HP, FROMME GA, HEYL CW and WILLIS JP (1985) Synopsis of the impact of artificially opening the mouth of the Bot River Estuary: Implications for management. Trans. R. Soc. S. Afr. 45 465-481.

CALEDON DIVISIONAL COUNCIL (1975) Unpublished Memorandum (No. VB 26/1).

DWAF (2002) Water Resource Protection Policy for the Implementation of Resource Directed Measures for Protection of Water Resources. Volume 5 Estuarine Ecosystems. Department of Water Affairs and Forestry, Pretoria. [Online]. Available (http//wwwdwaf.pwv.gov.za/idwaf/Documents/Policies/WRPP/Estuarine\% 20Ecosystems.htm).

FORBES AT (1978) Maintenance of non-breeding population of the estuarine prawn Callianassa kraussi (Crustatea, Anomura, Thalassinidae). Zool. Africana 13 33-40.

FROMME GA (1985a) Botriviervlei-Kleinmond Surveys. CSIR, National Research Institute for Oceanology, Sediment Dynamics Division, Stellenbosch. CSIR Report T/SEA 8604.

FROMME GA (1985b) The hydrology of the Bot River Estuary. Trans. R. Soc. S. Afr. 45 305-315.

HEYDORN AEF and TINLEY KL (1980) Estuaries of the Cape. Part 1. Synopsis of the Cape Coast. Natural Features, Dynamics and Utilization. CSIR, National Research Institute for Oceanography, Stellenbosch. CSIR Research Report 380.

HUIZINGA P and VAN NIEKERK L (1997) The Effects of Future Changes in Runoff on the Olifants Estuary. CSIR, Stellenbosch. CSIR Report ENV/S 97128.

HUIZINGA P and VAN NIEKERK L (1998a) Physical Dynamics of the Swartkops Estuary. CSIR, Stellenbosch. CSIR Report ENV/S 98024.

HUIZINGA P and VAN NIEKERK L (1998b) Klein River Estuary: The Effects of High Water Levels During Mouth Breaching in 1997. CSIR, Stellenbosch. CSIR Report ENV/S 98031.

HUIZINGA P and VAN NIEKERK L (1998c) Mkomazi Estuary: Physical Aspects. CSIR, Stellenbosch. CSIR Report ENV/S 98088.

HUIZINGA P and VAN NIEKERK L (1998d) Mhlatuze Estuary: Physical Aspects. CSIR, Stellenbosch. CSIR Report ENV/S 98106.

HUIZINGA P and VAN NIEKERK L (1998e) Nhlabane Estuary: Physical Aspects. CSIR, Stellenbosch. CSIR Report ENV/S 98107.

HUIZINGA P and VAN NIEKERK L (1999) Klein River Estuary: The Effects of Mouth Breaching in 1998. CSIR, Stellenbosch. CSIR Report ENV/S 99014.

HUIZINGA P, VAN NIEKERK L and WITHERS A (1997) Klein River Estuary: The Effects of High Water Levels During Mouth Breaching in 1996. CSIR, Stellenbosch. CSIR Report ENV/S 97016.

JEZEWSKI WA and ROBERTS CPR (1986) Estuarine and Lake Freshwater Requirements. Department of Water Affairs, Directorate of Planning Services, Pretoria. Technical Report No. TR 129.

KOOP K (1982) Estuaries of the Cape Part 2. Synopses of Available Information on Individual Systems Report No 18 Bot/Kleinmond System (CSW13). CSIR, National Research Institute for Oceanography, Stellenbosch. CSIR Research Report 417.

LAMBERTH SJ (2001) Personal communication. Researcher, Marine and Coastal Management, DEAT. Telephonic interview on 8 and 25 May 2001, in connection with regional coastal management, marine protected areas and estuarine dependent fish migration behaviour. 
LAMBERTH SJ and TURPIE JK (2003) The Role of Estuaries in South African Fisheries: Economic Importance and Management Implications. Water Research Commission Report No. 756/2/03, Pretoria.

MAREE RC, WHITFIELD AK and QUINN NW (2003) Prioritization of South African Estuaries Based on Their Potential Importance to Estuarine-Associated Fish Species. Water Research Commission Report No. TT 203/03, Pretoria.

MARTENS C (2001) Personal communication. Overberg Conservation Officer, CNCB, Hermanus. Interview on 22 September 2001 in connection with Bot and Kleinmond Estuary breaching observations.

MORANT P and QUINN N (1999) Influence of man and management of South African estuaries. In: Allanson BR and Baird D (eds.) Estuaries of South Africa. Cambridge University Press, Cambridge. 289-321.

NATIONAL WATER ACT, No 36 of (1998) Pretoria Department of Water Affairs and Forestry [Online]. Available http://wwwdwaf.pwv.gov.za/idwaf/Documents.

NOBLE RG and HEMENS J (1978) Inland Water Ecosystems in South Africa - A Review of Research Needs. South African National Science Programme, Pretoria. Report no 34.

PROCHAZKA K and GRIFFITHS C (2000) Cape Action Plan for the Environment: Final Report of the Estuarine Component. Zoology Department and Marine Biology Research Institute, University of Cape Town. Prepared for WWF-SA.

ROBERTS JR (2002) Personal communication. Breede Catchment Management Agency Manager, DWAF, Bellville. Interview on 14 October 2002, in connection with the state of the Bot River Catchment and the reduction in runoff to the estuary.

ROGERS J (1985) Geomorphology, offshore bathymetry and quaternary lithostratigraphy around the Bot River Estuary. Trans. $R$. Soc. S. Afr. 45 211-237.

SCHULTZ CB and WATSON MD (2002) Water Situation Assessment Model: A Decision Support System for Reconnaissance Level Planning, Theoretical Guide, Version 3. Department of Water Affairs and Forestry, Pretoria.

SLOAN AW, BRANCH GM and BALLY R (eds.) (1985) Research on the Bot River Estuary in relation to its management. Proc. Symp. held under the Auspices of the Royal Society of South Africa. Royal Society of South Africa, Cape Town.

STIPINOVICH A (2002) Land-use Change and Runoff Effects in the Bot River Catchment. Honours research report. Department of Geography and Environmental Studies, University of Stellenbosch, Stellenbosch.

TALJAARD S, HUIZINGA P, VAN NIEKERK L and SLINGER JH (1999) Manual: Approach and Methodologies Applied by the CSIR in Estuaries. CSIR, Stellenbosch. CSIR Report ENV-S-I 9916.
THE GREAT BRAK RIVER ENVIRONMENTAL COMMITTEE (GEC) (1990) The Great Brak River Environmental Study with Reference to a Management Plan for the Wolwedans Dam. CSIR, Stellenbosch. CSIR Report EMA-C9036.

TURPIE JK (2002) Classification and Prioritization of South African Estuaries on the Basis of Health and Conservation Priority Status for Determination of the Estuarine Water Reserve (3rd edn.). Department of Water Affairs, Pretoria.

TURPIE JK, ADAMS JB, JOUBERT A, HARRISON TD, COLLOTY BM, MAREE RC, WHITFIELD AK, WOOLDRIDGE TH, LAMBERT SJ, TALJAARD S and VAN NIEKERK L (2002) Assessment of the conservation status of South African estuaries for use in management and water allocation. Water SA 28 (2) 191-203.

V3 CONSULTING ENGINEERS (2000) Western Overberg Coastal Zone Water Supply: Catchment Analysis. Final Report - Volume 2.

VAN FOREEST DA (1985) Numerical model for the wind-driven circulation in the Bot River Estuary. Trans. R. Soc. S. Afr. 45 285289.

VAN HEERDEN I (1985) Barrier/Estuarine processes in Bot River Estuary - An interpretation of aerial photographs. Trans. R. Soc. S. Afr. 45 239-251.

VAN NIEKERK L and TALJAARD S (2003) Recommendations on a Framework for Effective Co-Operative Governance of South African Estuaries. Unpublished report of the Institute of Natural Resources. CSIR Report ENV-S-C 2003-077.

VAN NIEKERK L, TALJAARD S, VAN DER MERWE L, HUIZINGA P and SCHONEGEVEL L (2000) South African Estuaries. Data Report on Topographical Surveys for Selected Estuaries from 1985-1999. Vol I Northern Cape and Western Cape. CSIR, Stellenbosch. CSIR Report ENV-S-C 2000-120B.

VONK R (2000) Personal communication. Marine Surveyor, CSIR, Stellenbosch. Interview on 23 May 2000, in connection with the Botvlei estuary bathymetric survey.

WHITFIELD AK (1992) A characterisation of southern African estuarine systems. Afr. J. Aquat. Sci. 12 89-103.

WHITFIELD AK (1998) Biology and ecology of fishes in Southern African estuaries. Ichthyological Monographs of the JLB Smith Institute of Ichthyology, No. 2. NMB Printers, Port Elizabeth. 118 pp.

WHITFIELD AK and MARAIS H (1999) Ichthyofauna. In: Allanson BR and Baird D (eds.) Estuaries of South Africa. Cambridge University Press, Cambridge. 209-218.

WILLIS JP (1985) The bathymetry, environmental parameters and sediments of the Bot River Estuary. SW Cape Province. Trans. R. Soc. S. Afr. 45 253-283.

WOOLDRIDGE T (1999) Estuarine zooplankton community structure and dynamics. In: Allanson BR and Baird D (eds.) Estuaries of South Africa. Cambridge University Press, Cambridge. 141-166. 
